ISSN 2712-7729 International penitentiary journal, 2021, vol. 3(1-3), iss. 1

DOI 10.33463/2712-7737.2021.03(1-3).1.012-020

Niyazova S. S.

Ниязова С. С.

\title{
THE MAIN MEANS OF ENSURING A SENTENCE EXECUTION IN THE FORM OF RESTRICTION OF LIBERTY
}

\section{ОСНОВНЫЕ СРЕАСТВА ОБЕСПЕЧЕНИЯ ИСПОАНЕНИЯ НАКАЗАНИЯ В ВИАЕ ОГРАНИЧЕНИЯ СВОБОАЫ}

Abstract. Currently, the Republic of Uzbekistan is actively implementing reforms of the penal legislation and the penal system. Their main tendency is to abandon the previously dominant opinion about the possibility of reducing crime by toughening penalties and to choose a course for strengthening and developing legal norms that promote greater individualization and differentiation of criminal responsibility. However, we have to admit that the current system of punishments does not have measures that can achieve the goal of correcting convicted persons without elements of isolation from society, but under the supervision of competent law enforcement agencies. The relatively rare use of the restriction of liberty, in the author's opinion, is explained by the insufficient development of the mechanism for its implementation, in particular, the means of ensuring its execution. The execution of a sentence in the form of restriction of liberty is ensured by a whole system of means that are closely interrelated. Conditionally, such means can be divided into two main groups: control-supervisory and psychological-educational means. Based on the results of the study, the author comes to the following conclusions. The enforcing means of liberty restriction are designed to create a reliable legal guarantee of the implementation of the principle of punishment inevitability and the fullest possible realization of the goals of punishment. Currently, there is no practice in Uzbekistan of using electronic means of control and supervision of persons sentenced to restriction of liberty. At the same time, only the implementation of the electronic tracking tools specified in the legislation for the control and supervision of persons sentenced to restriction of liberty, the definition of a specific order and methods of surveillance can affect the development of positive experience in the use of electronic bracelets in the Republic of Uzbekistan. A special category of persons sentenced to restriction of liberty is juveniles. When conducting educational work with them, it is necessary to take into account the factors that affect their behavior. In this regard, it is proposed to create a public organization consisting of juveniles at the age of 14 to 18 years, located at the inspection of the sentences execution of the internal affairs bodies and conducting educational activities with juveniles sentenced to restriction of liberty.

(C) Niyazova S. S., 2021

(C) Ниязова С. С., 2021 
ISSN 2712-7729 International penitentiary journal, 2021, vol. 3(1-3), iss. 1

Keywords: Republic of Uzbekistan, criminal policy, penal system, criminal punishment, restriction of liberty, means of enforcement of punishment.

Аннотация. В настоящее время в Республике Узбекистан активно проводятся реформы уголовно-исполнительного законодательства и уголовно-исполнительной системы. Их основной тенденцией являются отказ от главенствующего ранее мнения о возможности снижения преступности путем ужесточения наказания и выбор курса на усиление и развитие правовых норм, способствующих большей индивидуализации и дифференциации уголовной ответственности. Однако приходится констатировать отсутствие в действующей системе наказаний мер, способных достичь цели исправления осужденных без элементов изоляции от общества, но под надзором компетентных правоохранительных органов. Сравнительно редкое использование ограничения свободы, на взгляд автора, объясняется недостаточной разработкой механизма его реализации, в частности средств обеспечения его исполнения. Исполнение наказания в виде ограничения свободы обеспечивается целой системой средств, которые тесно взаимосвязаны между собой. Условно такие средства могут быть подразделены на две основные группы: контрольно-надзорные и психолого-воспитательные средства. По результатам проведенного исследования автор приходит к следующим выводам. Средства обеспечения исполнения ограничения свободы предназначены для создания надежной правовой гарантии осуществления принципа неотвратимости наказания и максимально полной реализации целей наказания. В настоящее время В Узбекистане отсутствует практика применения электронных средств контроля и надзора за осужденными к ограничению свободы. Вместе с тем только реализация указанных в законодательстве средств электронного слежения для контроля и надзора за осужденными к ограничению свободы, определение конкретного порядка и методов наблюдения способны повлиять на развитие положительного опыта использования электронных браслетов в Республике Узбекистан. Особую категорию осужденных к ограничению свободы составляют несовершеннолетние. При проведении воспитательной работы с ними необходимо учитывать фракторы, влияющие на поведение несовершеннолетних. В связи с этим предлагается создать общественную организацию, состоящую из несовершеннолетних в возрасте от 14 до 18 лет, находящуюся при инспекции исполнения наказаний органов внутренних дел и проводящую воспитательные мероприятия с несовершеннолетними осужденными к ограничению свободы.

Ключевые слова: Республика Узбекистан, уголовная политика, уголовноисполнительная система, уголовное наказание, ограничение свободы, средства обеспечение исполнения наказания.

\section{Information about author / Сведения об авторе}

Salomat Saparovna Niyazova, Sc.D (Law), acting professor of the department of criminal law, criminology and anti-corruption, Tashkent State Law University, Tashkent, Republic of Uzbekistan, e-mail: s.niyozova@tsul.uz.

Саломат Сапаровна Ниязова, доктор юридических наук, и.о. профессора кафедры уголовного права, криминологии и противодействия коррупции, Ташкентский государственный юридический университет, г. Ташкент Республика Узбекистан, e-mail:s.niyozova@tsul.uz. 
ISSN 2712-7729 International penitentiary journal, 2021, vol. 3(1-3), iss. 1 14 RESEARCH ARTICLES / HAУЧHЫE CTATЬИ

\section{Recommended citation / Для цитирования}

Niyazova, S. S. 2021, 'The main means of ensuring a sentence execution in the form of restriction of liberty', International penitentiary journal, vol. 3(1-3), iss. 1, pp. 12-20, doi: 10.33463/2712-7737.2021.03(1-3).1.012-020.

Ниязова, С. С. Основные средства обеспечения исполнения наказания в виде ограничения свободы / С. С. Ниязова // Международный пенитенциарный журнал. - 2021. - Т. 3(1-3), № 1. - С. 12-20. - DOI : 10.33463/2712-7737.2021. 03(1-3).1.012-020. 
The ongoing reforms in the penal legislation, as well as the reform of the penal system of the Republic of Uzbekistan, are accompanied by a large-scale update and improvement of legislation, the formation of many new legal institutions that meet the principles of a democratic state, international standards for the protection of individual rights and liberties, and require the improvement of the criminal liability system, which must be humane and at the same time be effective in achieving the goals of punishment provided for in Article 2 of the Penal Code of the Republic of Uzbekistan (hereinafter - the PC of the Republic of Uzbekistan). Measures aimed at the gradual elimination of the sphere of criminal repression and the widespread use of punishments that are not related to the isolation of convicted persons from society, including such penalties as restriction of liberty, are no exception to the general trend of the development of national legislation. Of particular importance in modern conditions is the problem of ensuring the rights and legitimate interests of convicts guaranteed by the state, improving the measures of their social and legal protection in the conditions of serving a sentence. Another trend in the development of criminal policy is the rejection of the prevailing opinion in society about the possibility of reducing crime by increasing penalties and the choice of a course to strengthen and develop legal norms that contribute to greater individualization and differentiation of criminal responsibility. However, all proposals in this direction can be reduced to the thesis that there are no measures in the current system of punishments that can achieve the goal of convicts' correction without elements of isolation, but under the supervision of competent law enforcement agencies. The current state of development of criminal penalties that form an alternative to deprivation of liberty, primarily the institution of restriction of liberty, does not allow us to recognize the problem as solved, since there is no real practical mechanism for the execution of this type of punishment. Judicial practice shows that the restriction of liberty is imposed less often than other types of punishment. According to the Main Department for the Execution of Sentences of the Ministry of Internal Affairs, it is impossible to achieve the objectives of the penal legislation by imposing a sentence of restriction of liberty on a convicted person, since its implementation poses a number of tasks to the competent authorities, to which there are no answers either from a theoretical, practical, or legislative point of view. The above requires a fundamental improvement of the penal system of the Republic of Uzbekistan, the adoption of a new concept aimed at humanizing punishments, correcting the convicted person without isolating him from society, liberalizing the types of punishment, developing and applying new types of punishment that are not related to deprivation of liberty, involving professional psychologists in the process of re-education, using information technologies, in particular electronic means of control and supervision of convicts.

In order for any legal institution not only to be declared and have practical significance, it is necessary to provide a mechanism for the implementation of legal norms that establish certain rules in the normative document regulating the relevant legal relations. This is especially true for legal relations related to the implementation of legal responsibility. But the problem lies not only in legal nihilism, to which a considerable part of the population is subject, but also in the purely technical and technological aspects of the implementation of the adopted laws. This directly concerns the implementation of criminal penalties. The relatively rare use of the restriction of liberty, in our opinion, is due to the insufficient development of the mechanism for its implementation, in particular, the means to ensure its execution. The execution of a sentence in the form of restriction of liberty is provided by a whole system of means that are closely interrelated, forming a single complex. Conditionally, such means can be divided into two main groups: control-supervisory and psychological-educational means. 
ISSN 2712-7729 International penitentiary journal, 2021, vol. 3(1-3), iss. 1

At the same time, the fact of the difference between the means of enforcing the restriction of liberty and the means of correction is fundamental. In our opinion, the first analyzed category is broader in its content. The purpose of the means of enforcing the restriction of liberty is to create a reliable legal guarantee of the implementation of the principle of punishment inevitability and the fullest possible realization of the goals of punishment. Means of correction are focused only on achieving one of the goals of criminal punishment - correction.

In accordance with Article 7 of the Penal Code of the Russian Federation, the correction of a convicted person is the formation of lawabiding behavior, respect for the person, society, work, norms and traditions of the human community. The main means of convicts' correction are the established procedure for the execution and serving of a sentence (regime), socially useful work, educational work, general education and vocational training, vocational training and social impact. The means of correction are applied taking into account the type of punishment, the nature and degree of public danger of the committed crime, as well as the personality and behavior of the convicted person. Based on the provisions of Article 7 of the PC of the of the Republic of Uzbekistan, as well as scientific sources, we propose the following classification of convicts' correction means: means of supervision and control; regime of serving a sentence; labor; educational work; legal education; incentives and penalties; psychological and social work. We will give a description of each of the listed means of convicts' correction. At the same time, we will proceed from the logic, by virtue of which the sequence of the material presentation will be determined by the analysis of the two main groups into which the means of execution of the analyzed type of punishment are divided.

Control and supervisory measures are aimed at monitoring the behavior of a person sentenced to restriction of liberty in order to identify violations of the order of serving a sentence. At the same time, for the convenience of consideration, we propose to divide these activities into two groups: local and general. Local control and supervisory measures involve their implementation in a limited area, usually at the inspection's location. Examples of such measures are periodic visits by convicts to the relevant inspection for registration, or telephone calls by the inspector on a stationary phone installed at the place of the convict's residence. General control and supervision measures involve the use of electronic means of control and supervision that allow to obtain information about a person sentenced to restriction of liberty, not only at the place of residence, but also staying outside it, although, being enshrined in legislation, this type of control is not applied in practice. We believe that local control and supervisory measures have significant drawbacks. First, the initiative to visit the inspection for the purpose of registration is largely given to the convict himself, which is formally his duty, but in fact depends on his will. The initiative passes to the law enforcement agencies only if the convicted person did not appear within the established time limit. Secondly, phone calls are not always technically possible - not all apartments have fixed (home) phones.

General control and supervision measures are carried out using electronic means of control and supervision of convicts. We agree with the opinion of I. V. Borisenko (2012) that the use of technical means of control and supervision has three goals: prevention of crimes committed by persons sentenced to restriction of liberty; prevention of violations of the order and conditions of serving a sentence in the form of restriction of liberty; obtaining the necessary information about the behavior of persons sentenced to restriction of liberty.

Speaking about the practice of introducing electronic means of control and supervision over persons sentenced to restriction of liberty, it is worth noting that, for example, the Government of the Russian Federation Decree No. 198 adopted on 31.03.2010 approved a list of audio-visual, electronic and other technical 
means of supervision and control used by penal inspections to ensure supervision over persons sentenced to restriction of liberty. This list includes: electronic wristband, stationary monitoring device, mobile monitoring device, repeater, personal tracker, etc. However, it is an electronic bracelet that is worn on a person sentenced to restriction of liberty, and therefore we will pay special attention to this electronic means of monitoring and supervising convicts. An electronic bracelet is an electronic device that is worn on a person sentenced to restriction of liberty for the purpose of remote identification and tracking of his location, intended for longterm wear on the body (more than 3 months) and has a built-in system for monitoring unauthorized removal and opening of the case. The shape of the bracelet does not differ from the usual electronic watch. In the strap of the bracelet there is an LED drive, which instantly gives a signal to the operator in case of an attempt to remove it. The bracelet comes complete with a transmitter that can be hung on the belt and a stationary transmitting device that is installed at the place of serving the sentence. Depending on the restrictions imposed on the convicted person by the court, the prisoner is given one or another set from the specified list. If the prisoner is forbidden to leave the house at all, then it will be possible to limit him to a bracelet and a stationary module. This type of control and supervision is the most effective and acceptable to date, since it does not require any difficulties for the enforcement officers.

Thus, having considered the general control and supervisory measures of the inspection for persons sentenced to restriction of liberty, it can be concluded that at this stage electronic means of control and supervision should be introduced into law enforcement practice.

The next group of means of ensuring the execution of the analyzed type of punishment that is not associated with isolation from society is psychological and educational means. Criminal legislation provides for strictly defined goals of criminal punishment - the restoration of social justice, the correction of the person who committed the crime, and the prevention of the commission of new crimes. In this regard, A. N. Velichko (2006) notes that each punishment is able to carry out the tasks of both general and special prevention of crimes, which are achieved by assigning a fair punishment to the person who committed the crime. In our opinion, it is the effective organization of the process of punishment execution in the form of restriction of liberty that affects the development of the potential of criminal punishment and the achievement of its goals. So, if a person sentenced to restriction of liberty has not corrected himself and intends to commit a crime again, then it is possible to keep him from doing so only by the threat of a more severe punishment (Velichko, A. N. 2006). In the process of a sentence execution in the form of restriction of liberty, it is possible to achieve all the goals of criminal punishment. However, it should be emphasized once again that the achievement of the goals of punishment in the form of restriction of liberty is possible only after making appropriate changes to the criminal and penal legislation, which were discussed in this paper.

It seems that in connection with the emerging trend towards the reform of the penal system, it is the goal of correcting the convicted person through educational influence that causes the greatest number of complaints. We agree with the position of I. A. Podroykina (2007, p. 56), who believes that in criminal law correction is mainly implemented during a sentence, the achievement of a specific result correction of the convicted person is carried out in the process of the sentence execution in accordance with the penal legislation. The purpose of the correction of the convicted person is to change the personality, in which he returns to society as a citizen who does not violate the law and respects the rules of human society. A person becomes a criminal as a result of the negative influence of various criminogenic factors on the formation of his psychoemotional state. As a result, the potential criminal does not have a normal perception of 
ISSN 2712-7729 International penitentiary journal, 2021, vol. 3(1-3), iss. 1

all the events that occur, there is aggression and alienation from society.

However, speaking about the restriction of liberty, one can doubt the real corrective effect on the convicted person. In our opinion, the restriction of the rights of a convicted person while serving a sentence in the form of restriction of liberty does not contribute to the correction of his internal properties and behavior. At the same time, it is precisely to achieve this result that it is necessary to conduct educational work with the convicted person to restrict liberty, which is implemented by the penal inspections. At the same time, the ultimate goal of such education is the voluntary rejection of the convicted person from the environment that gave rise to criminal motivation in him. As G. G. Khantseva (2009, p. 102) points out "educational influence is a means of spiritual influence on the convicted person, an attempt to improve his personality by purposeful corrective influence, restoring or instilling in the convicted person the skills of correct orientation in the system of spiritual and moral values, psychological and other preparation for leading a socially useful life." In addition, the process of correction is greatly influenced by the age of the convicted person to the restriction of liberty. A special category of persons sentenced to restriction of liberty is juveniles. In our opinion, in order to conduct effective educational work with juveniles sentenced to restriction of liberty, it is necessary to take into account a number of factors:

- special psychophysiological and social qualities of a teenager's personality. It should be remembered that a juvenile is most susceptible to adverse influence from peers. A juvenile can either lag behind in development, or, conversely, overtake his age;

- the influence of narcotic and psychotropic substances on the behavior of a teenager. In the process of conducting educational work with a juvenile, the inspector should pay special attention to explaining the consequences of the use of narcotic and psychotropic substances for preventive purposes;
- lack of upbringing in a full family. Practice shows that the vast majority of teenagers who committed crimes were brought up in dysfunctional families. In this regard, we consider it necessary to recommend that the inspection staff and psychologists actively work with the families of juveniles, in particular, in order to identify the microclimate in the family, the influence of the immediate environment.

It should be noted that these factors should be taken into account when conducting educational activities with juveniles. In this case, there is again the problem of proper personnel who can be brought in to work with juveniles who have a completely different worldview and world perception, which must be taken into account when working with them. If one uses inappropriate methods of educational and psychological influence, then the juvenile may withdraw and not make contact during subsequent communication.

Special attention should be paid to conducting interviews with the convicted person. During the conversation, the inspection officer should not look cheeky, familiar, behave haughtily or show excessive perseverance. The inspection officer should behave politely, with restraint, tactfully and take into account the influence of unfavorable factors - tension, hostility, indifference, fear, uncertainty and other emotional manifestations of the educated (Chernysheva, D. V. 2010). Therefore, when conducting conversations of this kind, the correspondence acquaintance of the convicted person and the officer conducting the conversation can help. It can be expressed in positive information that the convicted person can receive from various sources. This will help to create the appearance of familiarity, trust, which is necessary for a frank conversation.

When imposing a sentence in the form of restriction of liberty, it is necessary to pay attention to the labor relations or educational activities of the convicted person, since, in our opinion, labor education is aimed at making the convicted person aware of the need to continue 
working or educational activities, since for the process of correction and adaptation, it is necessary to be a member of the team, which also affects the formation of positive thinking. Only being in a society, the individual is able to realize himself. It is important that employers do not turn away from those sentenced to the restriction of liberty, and give them an opportunity to improve. For example, in the Russian Federation, in the field of labor education, active assistance is provided to those sentenced to imprisonment and little is done for those sentenced to punishments that are not related to isolation from society (Khantseva, G. G. 2009, p. 102).

However, educational work will only be effective if it is carried out on an individual basis, since this is the only way to establish close psychological contact with the convicted person, to discuss in more detail the problems that have arisen, and to put the convicted person on the path to overcoming the negative influence of the criminal environment. There is an opinion that the greatest effectiveness of individual counseling can be achieved if certain conditions are met: the desire of the convicted person to change, the authority of the psychologist's personality, and the establishment of the necessary contact (Solonenko, N. \& Mel'nikova, A. 2007, p. 20). As you know, the main elements of individual educational work are:

- the study of the convict's personality, taking into account all its features;

- choosing the form of educational influence;

- implementation of the relevant action plan;

- conducting an analysis of the events results.

The first two elements are fundamental, and it depends on them whether the goals of the educational event will be achieved or not. The study of the personality of the convicted person is carried out during the entire period of serving his sentence. This process begins with filling out the personal file of the convicted person, studying his questionnaire. At this stage, it is important to assess the marital status of the convicted person, the level of his education and personality characteristics.

However, the implementation of the goals of any punishment, including the restriction of liberty, is fully achieved when the bodies implementing the punishment can apply incentives or penalties. Psychologically, a person is able to accept any way of life, against which he cannot protest, remaining alive. In other words, a person can get used to everything (Rozhkov, S. A. 2013). Criminal punishment is a time-consuming process, and in the course of this process, a person adapts to the circumstances in which he is forced to be. This, of course, makes it difficult to realize the goals of punishment, since the convicted person no longer thinks about what he has done, but simply continues to live the life in which he found himself while serving his sentence. A lot of hardships and restrictions quickly cease to be perceived as payback for what they have done, and begins to become a part of life, and if these hardships are significant for a person, he perceives them not as punishment, but as his own suffering, while less significant hardships become a habit.

In our opinion, the incentive measures are primarily aimed at correcting the motivation of the convicted person, encouraging law-abiding behavior at the time of serving the sentence, and putting him on the path of correction. Encouragement for correct behavior increases the desire to continue this way of behavior, that is, it acts positively. At the same time, according to the results of an anonymous survey of citizens, absolutely everyone noted that encouragement in any form has a positive effect on all types of activities and on behavior in general. In this regard, it is necessary to carry out measures to increase the use of incentive measures by the inspection staff.

Thus, we have considered the main means of ensuring the execution of punishment in the form of restriction of liberty, which allows us to draw some conclusions.

1. The means of enforcing the restriction of liberty are designed to create a reliable 
ISSN 2712-7729 International penitentiary journal, 2021, vol. 3(1-3), iss. 1

legal guarantee of the implementation of the inevitability principle of punishment and the fullest possible realization of the goals of punishment. Conditionally, they can be divided into control and supervisory and psychological and educational means.

2. Currently, there is no practice in Uzbekistan of using electronic means of control and supervision of persons sentenced to restriction of liberty. At the same time, only the implementation of the electronic tracking tools specified in the legislation for the control and supervision of persons sentenced to restriction of liberty, the definition of a specific order and methods of surveillance can affect the development of positive experience in the use of electronic bracelets in Uzbekistan.

3. A special category of persons sentenced to restriction of liberty is juveniles. When conducting educational work with them, it is necessary to take into account the factors that affect the behavior of juveniles. In this regard, we propose to create a public organization consisting of juveniles at the age of 14 to 18 years, located at the inspection of sentences execution of the internal affairs bodies and conducting educational activities with juveniles sentenced to restriction of liberty.

\section{References}

Borisenko, I. V. 2012, Organization and legal basis of the activities of penal inspections in the field of prevention of repeated crimes among convicted persons who are on record: PhD thesis (Law), Pskov.

Velichko, A. N. 2006, Activities of the Court for the prevention of crimes: PhD thesis (Law), Tyumen.

Podroykina, I. A. 2007, 'Goals of punishment', Legal Bulletin of the Rostov State University of Economics, iss. 2, pp. 56-59.

Khantseva, G. G. 2009, 'Analysis of the problem of correction in the penitentiary system in Russia', The world of science, culture, and education, iss. 4, pp. 100-103.

Chernysheva, D. V. 2010, Organizational and legal basis for the activities of penal inspections to attract convicts to serve mandatory and correctional labor: PhD thesis (Law), Ryazan.

Solonenko, N. \& Mel'nikova, A. 2007, 'Organization of psychological work with convicts without isolation from society', Vedomosti of the penal system, iss. 2, pp. 19-21.

Rozhkov, S. A. 2013, 'Some features of the punishment execution in the form of restriction of liberty', Bulletin of the Perm University, Legal Sciences, iss. 4, pp. 292-298.

\section{Библиографический список}

Борисенко И. В. Организация и правовые основы деятельности уголовно-исполнительных инспекций в сфере предупреждения повторных преступлений осужденных, состоящих на их учете : автореф. дис. ... канд. юрид. наук. Псков, 2012. 24 с.

Величко А. Н. Деятельность суда по предупреждению преступлений : автореф. дис. ... канд. юрид. наук. Тюмень, 2006. 16 с.

Подройкина И. А. Цели наказания // Юридический вестник Ростовского государственного экономического университета. 2007. № 2. С. 56-59.

Ханцева Г. Г. Анализ проблемы исправления в уголовно-исполнительной системе в России // Мир науки, культуры, образования. 2009. № 4. С. 100-103.

Чернышева Д. В. Организационные и правовые основы деятельности уголовно-исполнительных инспекций по привлечению осужденных к отбыванию обязательных и исправительных работ : автореф. дис. ... канд. юрид. наук. Рязань, 2010. 22 c.

Солоненко Н., Мельникова А. Организация психологической работы с осужденными без изоляции от общества // Ведомости уголовно-исполнительной системы. 2007. № 2. С. 19-21.

Рожков С. А. Некоторые особенности исполнения наказания в виде ограничения свободы // Вестник Пермского университета. Юридические науки. 2013. № 4. С. 292-298. 